\title{
ドロマイ「を利用せる陶磁器製㗐㤐關する研究 (1)
}

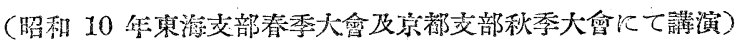

小川彩 一 郎

我國陶磁器工業の中心地である御當地(名古屋)の本大會席上で肪語を申し上げる機會を得ました事は洵に欣 幸に存じます。

演題はドロマイトを利用やる陶磁器製造に關する研究となつて居りますが本日は白雲陶磁器に就いて牧話し

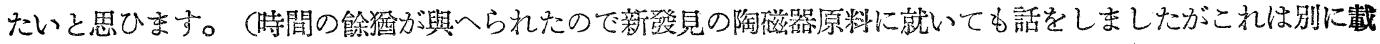
せたいと思つてるます)。

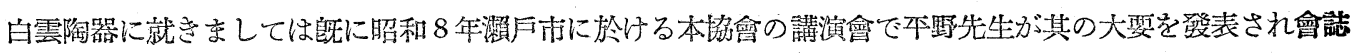
(第 41 集, 第 491 號, 昭 8, 11) にも記載されて居りますし又陶磁器試驗所の試作品を各所で展觀してるま

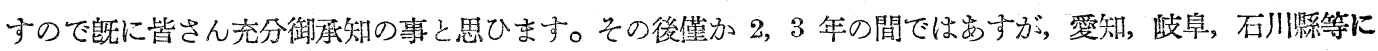
於きまして相當工業化せられ海然にも淮出し㕸め, 所期の目的を達しつ」めりますことは洵に心强く存じてる る次第であります。濐には是が工業化の急を要し末す所から其の大要を發表されたに過ぎませず科學的根據が 明らかになつてるませんでしたので爰に本日迄研究を致しました結果を少し詳しく申し上げたいと思ひます。 併し未だ砋究を完了したのではありまやんから後日再び蛙話する機會を得たいと思つてるます。

\section{供 試 原 料}

先づ使用原㮶から电し上げなすと，

1.白雲石一は石灰石に䓕だよく類似してるまして其の暞堂は炭酸苦士の存在にあり末す。石灰石の主成分は 炭酸カルシウムでありますが，白雲石は是と炭酸マグネショムとの復臨で正式のものは $\mathrm{CaCO}_{3} \mathrm{MgCO}_{3}$ 郎ち 1

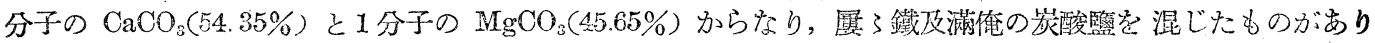

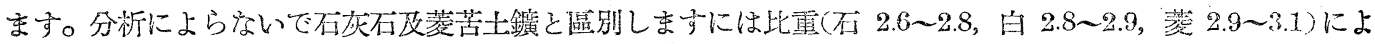

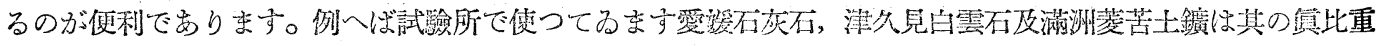
各了 $2.71,2.83$ 束 2.99 で山り市す。

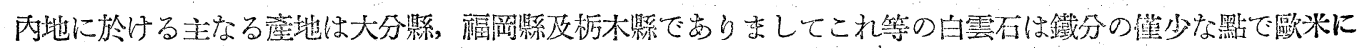

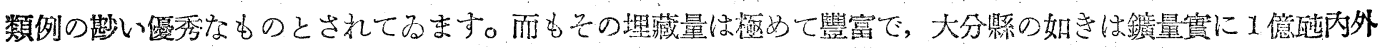

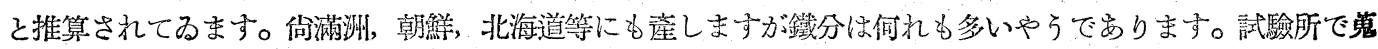
集しました內地產白雲石の化學分析はこの表(第1表)のやうであります。 
第 1 表白雲石の分析表

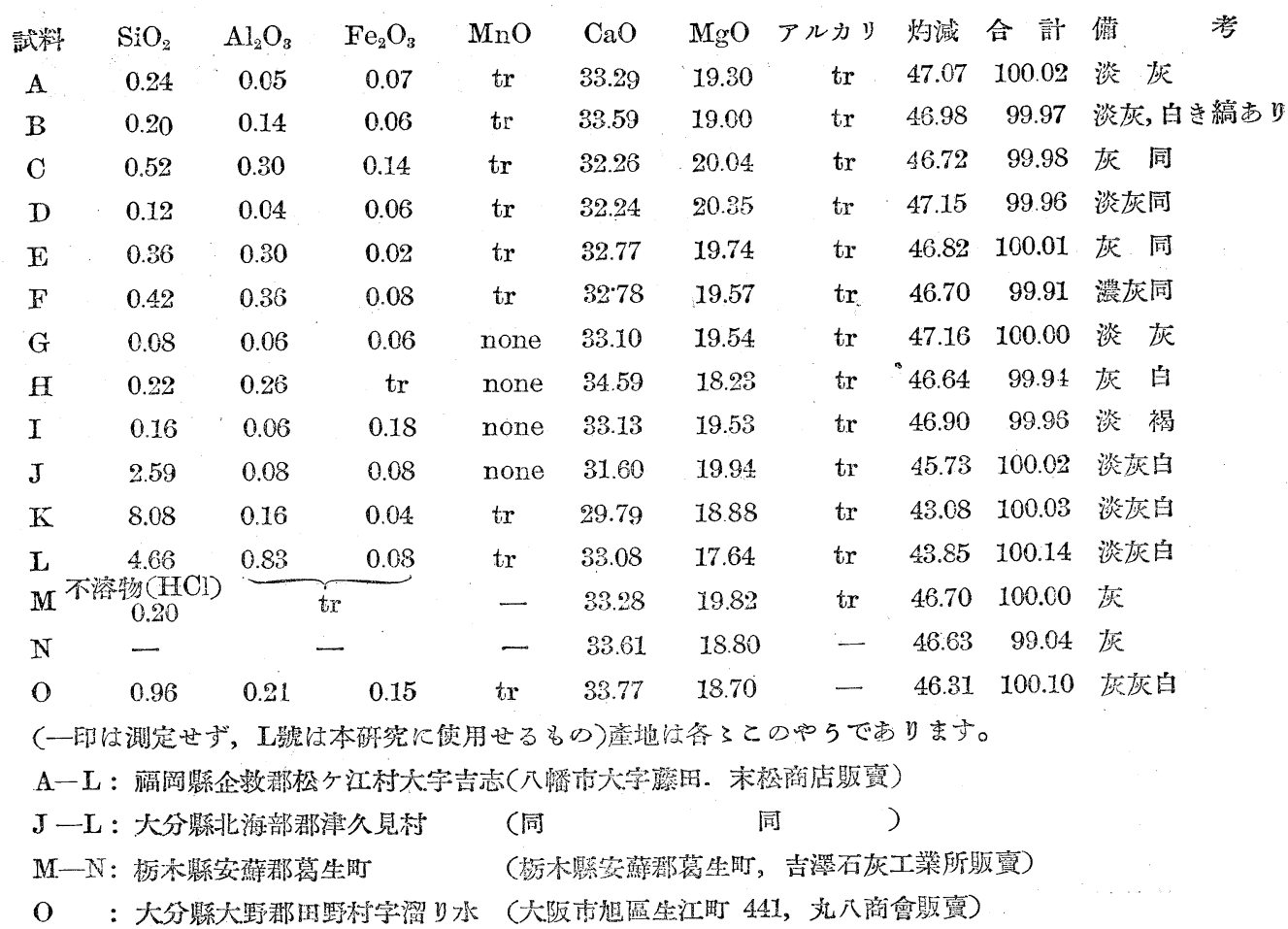

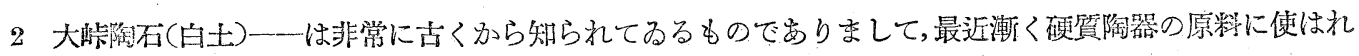
るゃらになりましたが，まだ廣く一般に用ひられてはるません。これは石英粗面岩の分解によつて生じたもの

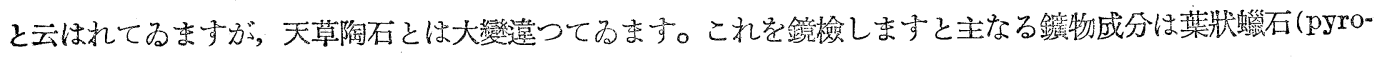

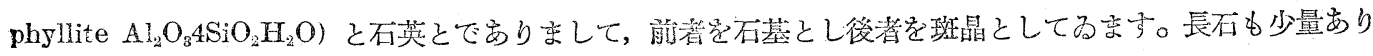
ますが可成り分解されてるます。カオリンも存在するやうですが鏡下には磪認出來なせんでした。原石をスタ

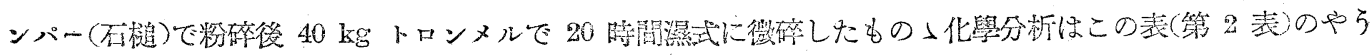

で岁り案す。

第 2 表 大踪陶石の分析表

\begin{tabular}{|c|c|c|c|c|c|c|c|c|c|c|c|}
\hline 大䟖隔存 & $\mathrm{SiO}_{2}$ & $\mathrm{TiO}_{2}$ & $\mathrm{Al}_{2} \mathrm{O}_{3}$ & $\mathrm{Fe}_{2} \mathrm{O}_{3}$ & $\mathrm{CaO}$ & $\mathrm{MgO}$ & $\mathrm{K}_{2} \mathrm{O}$ & $\mathrm{Na}_{2} \mathrm{O}$ & 灼減 & 諃 & 火度 \\
\hline 1 & 72.50 & 0.25 & 20.13 & 0.32 & 0.28 & 0.12 & 2.12 & 0.32 & 4.03 & 100.07 & - \\
\hline 2 & 74.60 & 0.26 & 17.86 & 0.14 & 0.12 & 0.10 & 0.08 & 0.23 & 6.66 & 100.05 & - \\
\hline 3 & 74.20 & 0.25 & 18.07 & 0.10 & 0.04 & tr & 0.14 & 0.26 & 6.87 & 99.93 & $\mathrm{~K} 301 / 2$ \\
\hline
\end{tabular}

(3 號は本研究に使用なるもの)

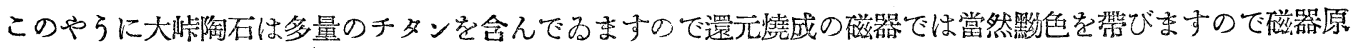
料には適當と言へません, そこで本研究の陶器原釈に活用することにしました。

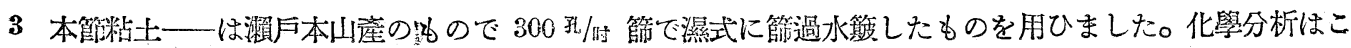
の表のやうであります。 
第 3 表 本山木䈟粘土水籍物の分析表

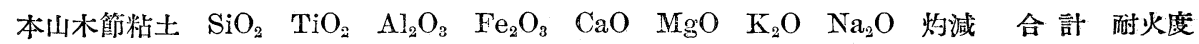

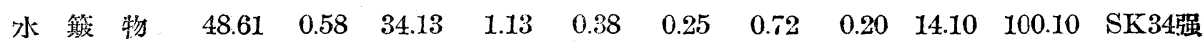

\section{混合物の晾化點}

白雲陶器は品質上 1 種の軟質陶器(こ〉に一寸继致りしますが致質と申しますのは Soft をかく解したの でありまして，硬質 Hard はその反對であります。强火度燒成の製品は低火度燒成のものより一般に質堅硬 度なるのが多いため, や〉ともすると製品の强弱を本來の意味とするやうに解されてるることが㞗々あります ので敢て附言致します。水に硬水と軟水とがあるやうに陶磁器の硬軟は耐火度, 融熔度或は堯成溫度の高低を 示すものと致します) でありますから，光づ各原料混合物の耐火度(軟化點)を測定しました。その結果はこの 㽞(第 1〜4 圖)のや弓であります。併し SK11 以上は测定しませんでした。

第 1 圖 軟化點(大峠陶石一白需石, 木節粘土一白雲石)

第 2 圖 乾化點(木節粘土一大峠陶石一白零石)

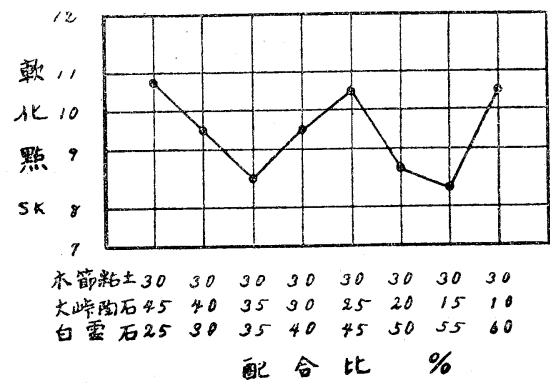

第 3 圖 軟化點(木節粘土一大峠陶石一白雲石)

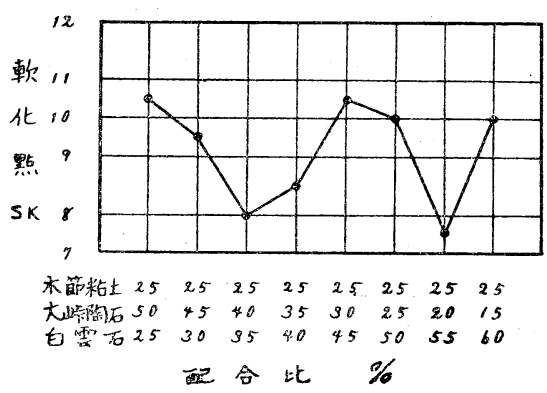

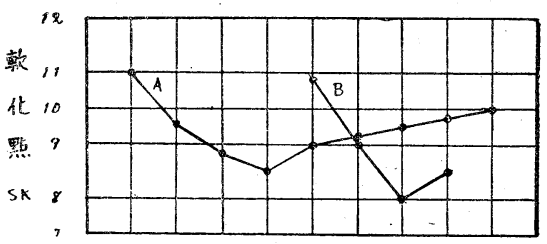

A

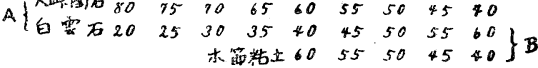
配合比\%

第 4 圖 軟化點(木節粘土一大怔陶石一白雲石)

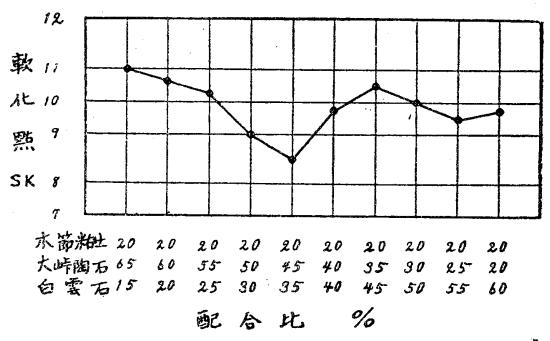

このやうに(1)本節粘土 $50 \%$ ，白雲石 $50 \%$ なる混合物は兩者の共融體でありまして，軟化點は SK8 であ ります。(2)大䦽陶石 $65 \%$ ，白雲石 $35 \%$ る混合物は兩者の最低熔融混合物であります。(3)又木笁粘土，大 捗陶石及白雲石の 3 者間には木節粘土 30 ～20\%の場合を通じ，白雲石 $35 \%$ 及 $55 \%$ の場合に各々二つの最低 熔融混合物を生じまして軟化點はSK8 1/2〜8 及 SK9 1/2〜 7 1/2であります。(4)そして白雲石の添加量60 \%以下のものに耐火度 SK11 以下゙のものが得られました。

\section{坛驗素地}

この結果から白雲石の配合量 15 60\%の範園內で耐火度 S K11 以下の軟質の素地が得られることが制りょ したが，白雲石を過量に用ひますと釉藥に惡響影があら（と考慮致しまして，試驗素地は白雲石を $40 \%$ 迄に 
制限致しました。又木節粘土の添加量も煩雜を避けて $25 \%$ に一定しこの表(第 4 表)の範園に止めました。

第 4 表 坏土の配合比(\%)

$\begin{array}{lrrrrrrrrr}\text { 記 號 A } & 1 & 2 & 3 & 4 & 5 & 6 & 7 & 8 & 9 \\ \text { 木節粘土 } & 25 & 25 & 25 & 25 & 25 & 25 & 25 & 25 & 25 \\ \text { 大峠陶石 } & 75 & 70 & 65 & 60 & 55 & 50 & 45 & 40 & 35 \\ \text { 白 雲 石 } & - & 5 & 10 & 15 & 20 & 25 & 30 & 35 & 40 \\ \text { 合 計 } & 100 & 100 & 100 & 100 & 100 & 100 & 100 & 100 & 100\end{array}$

\section{蟯 成 收 縮 率}

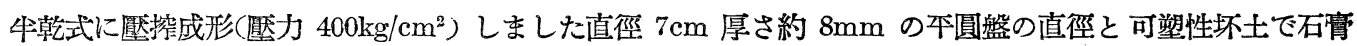
型で成形しました直俓 $8 \mathrm{~mm}$ 長さ $7 \mathrm{~cm}$ 狄棒の長さとを基準にして燒成收縮率を測定しました。この圖（第 5 圖)はその結果であります。

第 5 圖 燒縮率の變化(マッフル荳燒成， $7 \mathrm{~cm}$ 平圓盤）

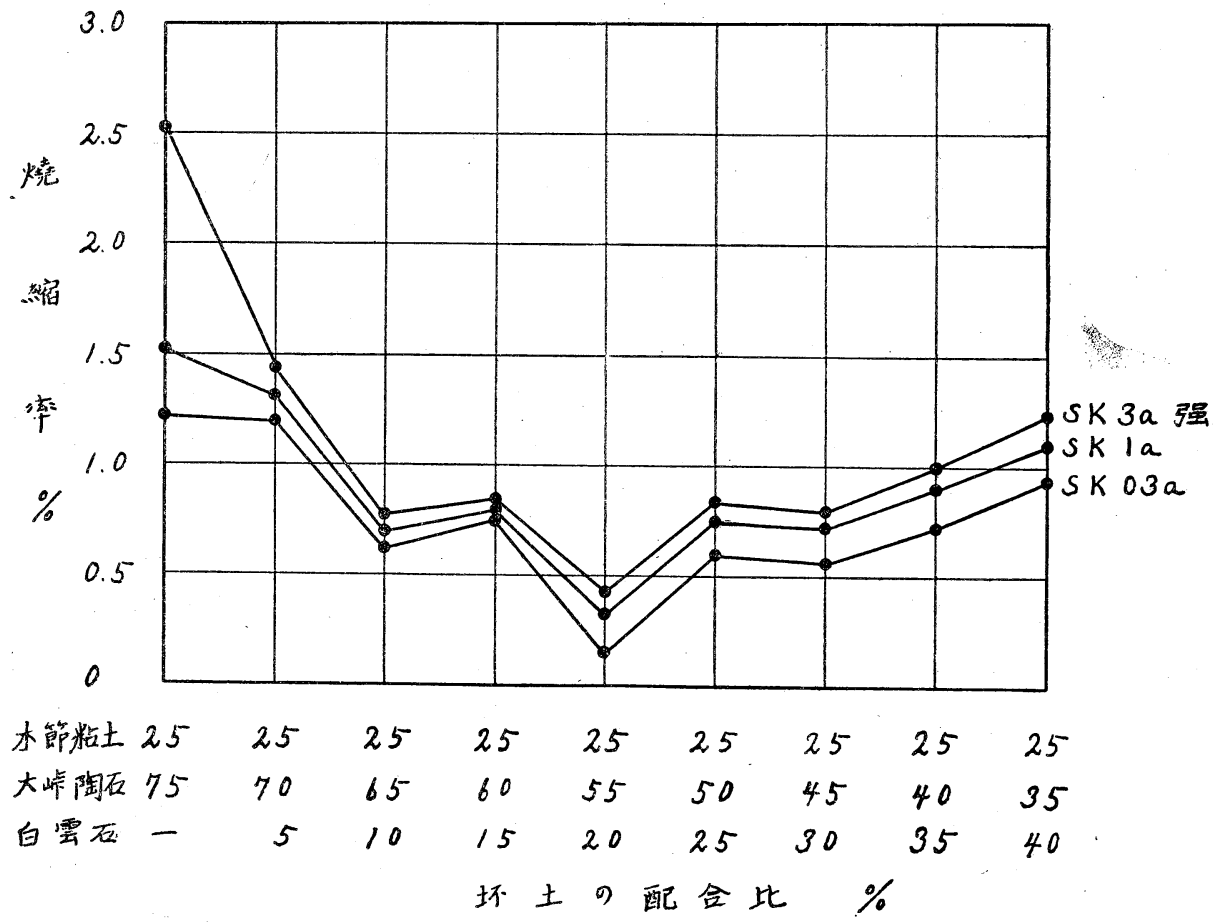

このやうに(1)白雲石を添加しますと何れの燒成溫度に於きましても最初 $20 \%$ 迄は次第に燒縮率を減少しま して，20\%から 40\%になりますと僅かに增加してくる傾向があります。この間 $15 \%$ と $25 \%$ の調合物に少し 特異性があるやらに見受けられます。(2) 第 5 圖と第 6 圖とを比較して見ますと，成形法と供試體の形狀と雐 成方法とによりまして燒縮率は多少違ひますが，白雲石の增加と燒縮率暒減の傾向 とは全く一致しました。 (3)唯還元燒成の場合に白雲石 $20 \%$ 以上のものが可なり著しく收縮するやうな結果を示しました。(4)叉この 調合の範圍內で耐火度の最も低いものは白雲石 $35 \%$ の坏土であり, 燒縮率の最も少いものは $20 \%$ のもので ありまして，前者が燒锭率最大でなく，後者が酎火度最大でないことから考へまして，この燒成溫度の範圍で 
は燒縮率と耐火度とに深い關倸がないやろであります。（5）要するに白雲石は燒縮率の極めて少い陶器を造る

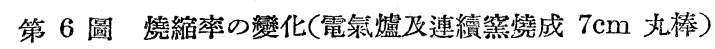

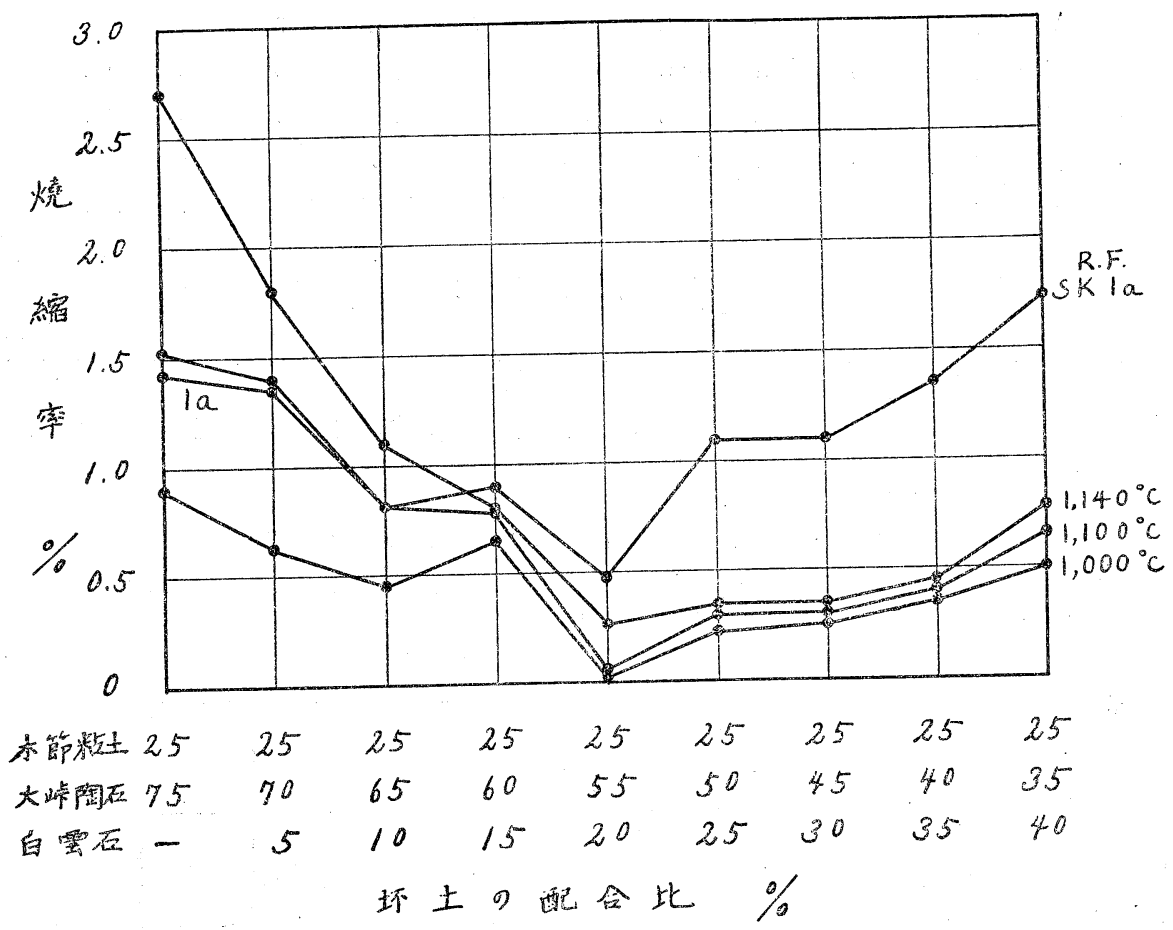

のに有效であることがハッキリ制りました。そして燒成溫度が $100^{\circ} \mathrm{C}$ 以上變りましても燒縮率が左程變らん と云ふ面白い事實が突き止められました。

\section{抗折强度}

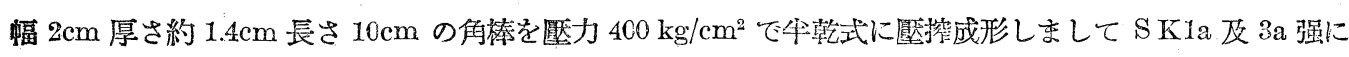

第 7 圖 抗 折 强 度

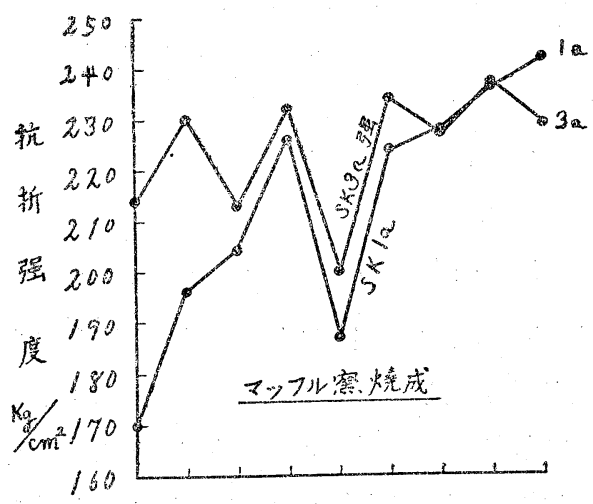

木節粘土252525252525252525

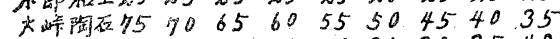
舅石一 510152025303540 配合比 \%

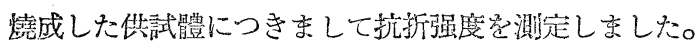
その結果はこの圖 (第 7 圖) のやうでありまして,(1) 1a

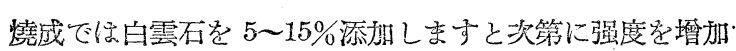
しまして、燒䋨率の最も少い20\%の所でガタリと減少しま す，そして 25〜 40\% になりますと再び强度定堌加するや らな㑯向が見受けられます。（2）3a 强燒成では一般に1a より少し强度が增えまして，15２5\% の那が 1a の場合 と一致しましたが他は强度が上下致しまして制然とし た傾向が制りませんでした。この點につきましては後程再 試驗の結果で補らことに致しますが忽に牢大體 220 230 $\mathrm{kg} / \mathrm{cm}^{2}$ 程度の强さのある素地が得られると云ふことだけ はハッキリ致しなした。 


\section{比重及有孔度}

抗折强度を測定しました供試體の破片の內で, 最高の强度を示しましたものと最低の强度を示しましたもの との 2 個につきまして㖵の比重と見掛の比重とを測定しまして有孔度を計算しました。その結果はこの圖(第 8 及 9 圖)のやうでありまして,

第 8 圆钿の此重及見掛の此重

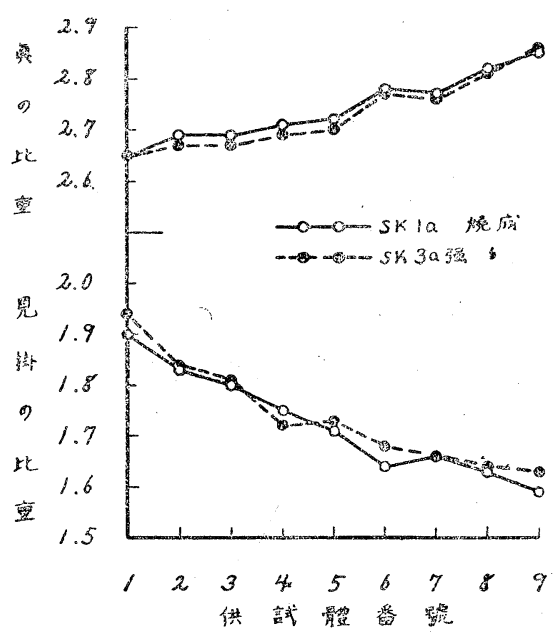

第 9 圖 眞 の有孔度

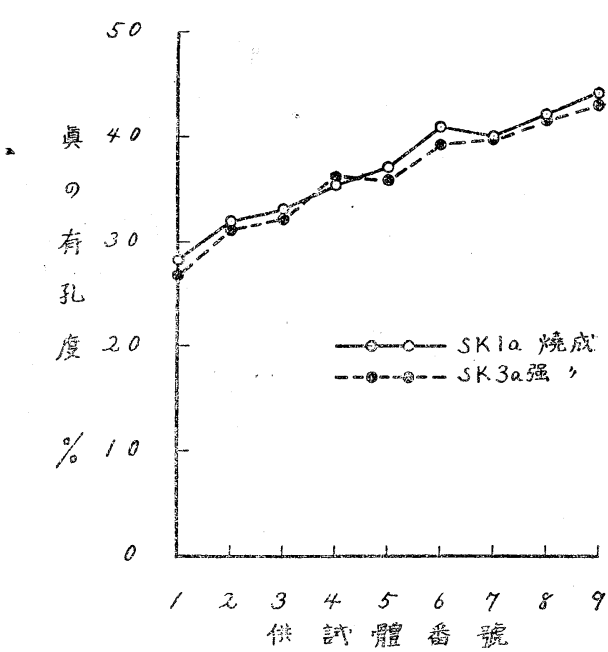

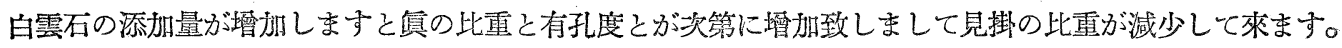
$1 \mathrm{a}$ と $3 \mathrm{a}$ 强との燒成に大きい差い認められませんが, 白雲石 $25 \%$ の素地に少し特異性がありそうに思はれま

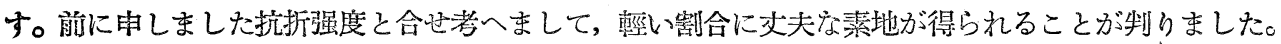

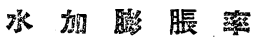

一般に陶器類の缺點とします所は年數が經つてから釉藥に鼠裂を生じてくることでありまして，これは跳に 皆さん充分御承知の通りであります。硬質陶器では一般に强く締㘹した方が安全であることが一般の常識とな

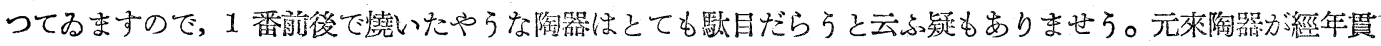
孔を生じます原因には色々ありをすが，素地が水や濕氣を吸つて膨脹すると云らことが大きな一つの原因であ りますことはこれ亦皆さん充分衘承知の所でありませう。そこでオートクレーブを用ひ恋して 4,8 及 $12 \mathrm{~kg} / \mathrm{cm}^{2}$ の堅力下で素地の水加膨脹率を測定しました。その結果はこの圖(第10１3圖)に示しましたやろで，

(A) 白雲石は水加膨脹率を減少するのに極めて效果的であります。郎ら (1) $1000^{\circ} \mathrm{C}(\mathrm{SKO} \mathrm{a}$ ) 燒成では白雲石 $25 \%$ まで急激に水加膨脹率究減少しまして 35４0\% では零になります。(2) 燒成溫庋が高くなりまして1100 ${ }^{\circ} \mathrm{C}(\mathrm{SK} 1 \mathrm{a})$ 及 $11400^{\circ} \mathrm{C}(\mathrm{SK} 3 \mathrm{a})$ になりますと自雲石 15\%まで急激に膨脹率が減りまして，15〜25\%の間で少し變

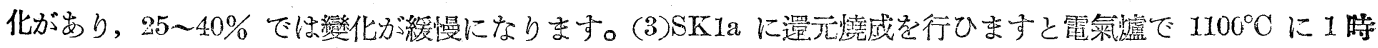

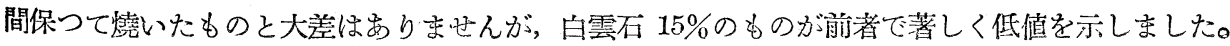

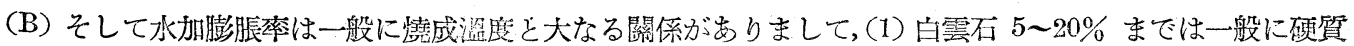
陶器と同樣燒成溫度が高ければ水抈膨脹率は低下します。これに反しまして 25〜 40\% になりますと硕質陶器 
の場合と反對に燒成溫度が高くなると水加膨脹率が大きくなります。これは傎に面白い現象で此種陶器の一特

第 10 圖 水 加膨脹率

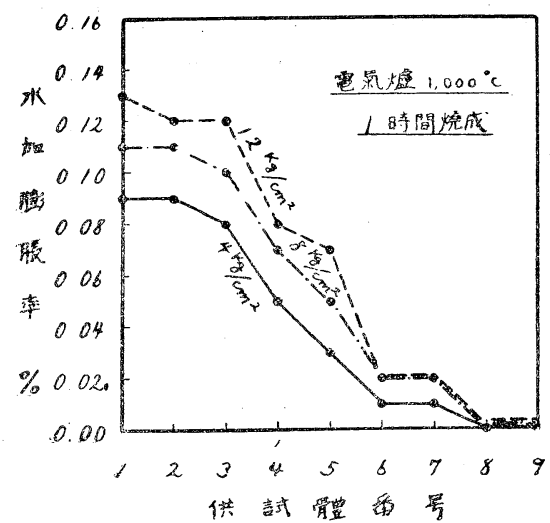

第 12 圖 水 加膨脹 率

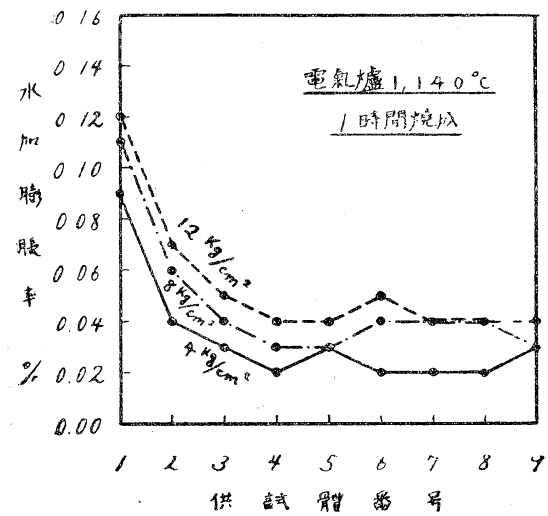

第 11 圆 水加膨脹 率

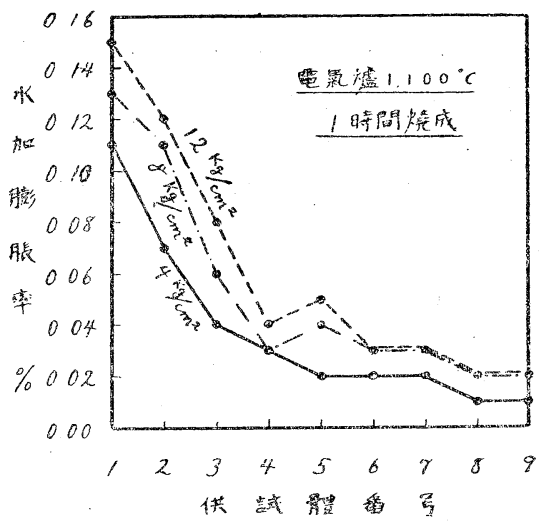

第 13 圆水加膨脤率

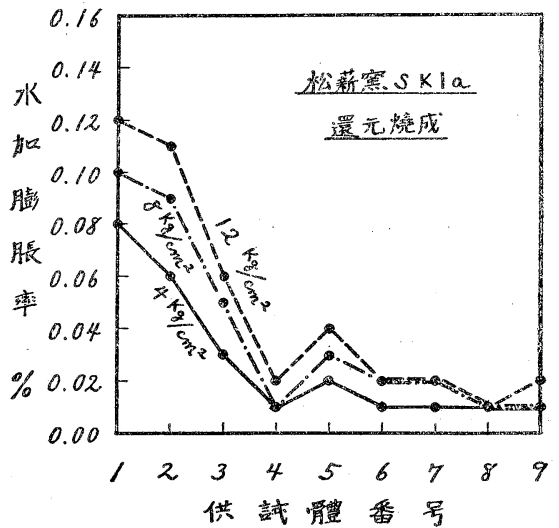

徵がこつに在ることがハッキリ制りました。

（C）今一つ面白い現象は白雲石 $15 \%$ までの素地は 前に申しました燒成收縮率と大體正比例しますが，燒縮 率の最も少い $20 \%$ 素地は水加膨脹率が特に大でありまして，25\% 以上は燒蛨率は大きくなりますが水加膨脹 率は寧ろ少くなりまして反比例します。

（D）それからオートクレーブ試驗に於きまして壓力を增加しますと水加膨脹率は大きくなりましたっ㐼し 白雲石 $25 \%$ 以上の素地では $8 \mathrm{~kg} / \mathrm{cm}^{2}$ と $12 \mathrm{~kg} / \mathrm{cm}^{2}$ とに大差がありませんでした。

要するに白雲石 5 40\%の素地では $20 \%$ の素地を中心に致しまして性質がハッキリ二樣に別れます。そし て低火度で安定な素地としましては白雲石 $25 \sim 40 \% の$ 素地が良好で山ることが決定出來ました。

\section{施秞體のオートクレーブ試驗}

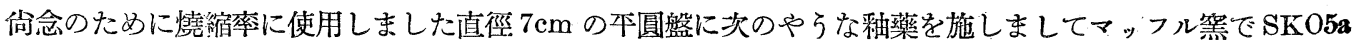
に釉燒しまして，オートクレーブで貫孔が出るかどうかを試驗しました。併し一度燒き損じましまして試驗體 が不足しまして 3〜5 個についてしか試驗が出來ませんでしたので，この表(第 5 表) はこડに參考として御 
說明する程度に致しまして，後程再試驗の結果を敀話して補足することに致します。

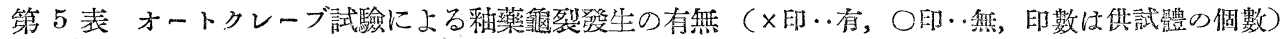

\begin{tabular}{|c|c|c|c|c|c|c|c|c|}
\hline 素地 & \multicolumn{7}{|c|}{ SKO3a 締 燒 } & \\
\hline 香影 & \multicolumn{3}{|c|}{ 58日緭過 } & $4 \mathrm{~kg} / \mathrm{cm}^{2}$ & \multicolumn{2}{|c|}{$8 \mathrm{~kg} / \mathrm{cm}^{2}$} & \multicolumn{2}{|c|}{$12 \mathrm{~kg} / \mathrm{cm}^{2}$} \\
\hline 1 & \multicolumn{3}{|c|}{$x \times \times \times x$} & - & \multicolumn{2}{|c|}{-} & $\ldots$ & \\
\hline 2 & \multicolumn{3}{|c|}{$x \times \times \times \times$} & - & \multicolumn{2}{|c|}{-} & $\ldots$ & \\
\hline 3 & \multicolumn{3}{|c|}{$x \times x \times x$} & - & \multicolumn{2}{|c|}{-} & $\ldots$ & \\
\hline 4 & \multicolumn{3}{|c|}{00000} & 00000 & \multicolumn{2}{|c|}{$000 \times x$} & \multicolumn{2}{|l|}{$x \times x$} \\
\hline 5 & \multicolumn{3}{|c|}{00000} & $x \times x \times x$ & \multicolumn{2}{|c|}{-} & \multicolumn{2}{|c|}{-} \\
\hline 6 & \multicolumn{3}{|c|}{00000} & 00000 & \multicolumn{2}{|c|}{$00000^{\prime \prime}$} & \multicolumn{2}{|c|}{$0000 x$} \\
\hline 7 & \multicolumn{3}{|c|}{00000} & 00000 & \multicolumn{2}{|c|}{00000} & \multicolumn{2}{|c|}{$00 \times \times \times$} \\
\hline 8 & \multicolumn{3}{|c|}{00000} & 00000 & \multicolumn{2}{|c|}{00000} & \multicolumn{2}{|c|}{00000} \\
\hline 9 & \multicolumn{2}{|c|}{00000} & & 00000 & \multicolumn{2}{|c|}{00000} & \multicolumn{2}{|c|}{00000} \\
\hline 素地 & & SK1a & 絖 燒 & & & SK3a & 縍 煒 & \\
\hline 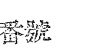 & 58 日經過 & $4 \mathrm{~kg} / \mathrm{cm}^{2}$ & $8 \mathrm{~kg} / \mathrm{crn}^{2}$ & $212 \mathrm{~kg} / \mathrm{cm}^{2}$ & 58 日經過 & $4 \mathrm{~kg} / \mathrm{cm}^{2}$ & $8 \mathrm{~kg} / \mathrm{cm}^{2}$ & $12 \mathrm{~kg} / \mathrm{cm}^{2}$ \\
\hline 1 & $x \times x$ & - & - & - & $x \times x$ & - & - & \\
\hline 2 & $x \times x$ & - & - & - & $x \times x$ & - & $\longrightarrow$ & - \\
\hline 3 & $x \times x$ & - & - & - & 000 & $x \times x$ & - & - \\
\hline 4 & 000 & 000 & 000 & $00 x$ & 000 & 000 & 000 & 000 \\
\hline 5 & $x \times x$ & - & - & - & $0 \times x$ & $x$ & - & - \\
\hline 6 & 000 & 000 & $00 x$ & 00 & 000 & 000 & 000 & 000 \\
\hline 7 & 000 & 000 & 000 & 000 & 000 & 000 & $00 x$ & 00 \\
\hline 8 & 000 & 000 & 000 & $00 x$ & 000 & 000 & 000 & $x \times x$ \\
\hline 9 & 000 & 000 & 000 & 000 & 000 & 000 & $x \times x$ & \\
\hline
\end{tabular}

フリット化學式

嬏藥化學式

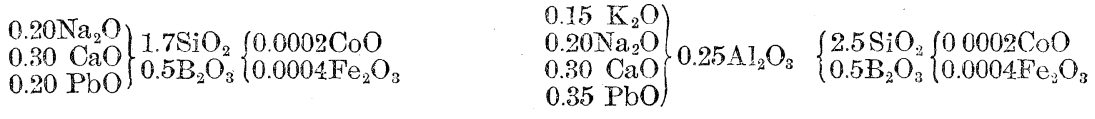

フリット文釉菜の配合割合

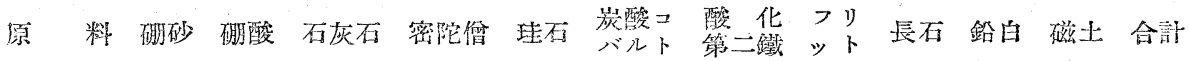

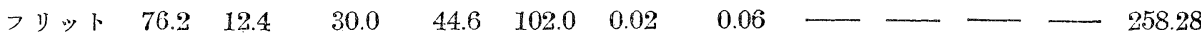

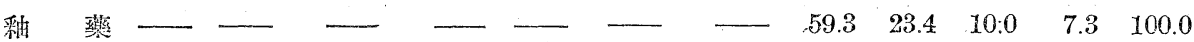

この結果は前に申し上げました水加膨㖘性と大體一致するやうでありまして,(1) 白雲石 10\%迄は全く不安

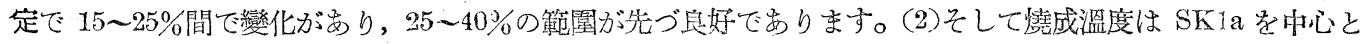
しまして，SK3a 强より SKO3a の方が却つて安定であります。（續） 